Article

\title{
One Village One Product (OVOP)—A Rural Development Strategy and the Early Adaption in Vietnam, the Case of Quang Ninh Province
}

\author{
Long Hoang Thanh ${ }^{1,2, *}$, Linh Ta Nhat ${ }^{3}$, Hao Nguyen Dang ${ }^{1}$, Thi Minh Hop Ho ${ }^{2}$ and \\ Philippe Lebailly ${ }^{2}$ \\ 1 University of Economics, Hue University, Hue City 530000, Vietnam; ndhao@hce.edu.vn \\ 2 Economics \& Rural Development, Gembloux Agro-Bio Tech, University of Liège, Liège 4000, Belgium; \\ mhop75@yahoo.com (T.M.H.H.); philippe.lebailly@uliege.be (P.L.) \\ 3 School of Banking and Finance, National Economics University, Ha Noi 100000, Vietnam; \\ tanhatlinh@gmail.com \\ * Correspondence: hoangthanhlong@hce.edu.vn
}

Received: 29 October 2018; Accepted: 26 November 2018; Published: 28 November 2018

check for updates

\begin{abstract}
Agriculture and rural development has continuously been a hot debate and received significant attention from literature. In this context, endogenous development is considered to be basic approach for rural development strategies in many countries of which the Japanese model namely One Village One Product (OVOP) is a successful one. This paper studies the OVOP movement and analyzes its early adaption in Vietnam, the so-called One Commune One Product (OCOP). This question is addressed by reviewing the existing literature on OVOP following by a case study in Quang Ninh province, Vietnam. The results, reveal, in practice, despite some criticism, OCOP strategy in general generate employment opportunities, incomes; enhance creativity and capability of local people.
\end{abstract}

Keywords: endogenous development; one village one product; one commune one product; traditional agriculture products; Quang Ninh; vietnam

\section{Introduction}

There have been numerous evidences in academic literature argue in favor of the rapidly increasing inequality in food security, health services, primary education, living standard, the declining importance of agriculture sector, the widening income gap between rural areas and prosperous urban areas across European, Latin American, African and Asian countries [1-6]. Territorial dynamics, population dynamics and the globalization dynamics have been believed to be key determinants after this different performance in rural areas [1,7-9]. In this context, territorial dynamics firstly takes into account entirely particular resources, assets and actors relating to a rural territory as a possibly crucial element for the development [10]. Secondly, population dynamics not simply bases on natural growth, but also result from migration. Migrants are a different set of economically active individuals, pensioners and return migrants [1]. Thirdly, the globalization dynamics namely the increasing trade and capital flows may be still considered to be an significant issue donating to the widening regional inequality [11].

Since the integration to the global economy, in front of challenges for rural development due to the trend of labor migration to urban areas, industrial zones, difficult access to credit, market, social inequality [12-15], Vietnamese government has issued many policies, series of national programs, focusing on agriculture, rural development [16-20]. Nevertheless, Vietnam's economy has been still 
heavily dependent on agriculture. Agriculture accounts for about $20 \%$ of the total GDP. About $50 \%$ of workforce is active in the agricultural sector and agricultural production covers $13 \%$ of total export revenue [21-23]. This is due to the fact that these approaches mainly focus on supporting and implementing "exogenous" projects namely new varieties, new techniques, and new loans to produce. This oriental production schemes put farmers in a difficult position, forcing them to perform with the full function of an enterprise, taking into consideration capital management, production organization, market research, product development, and marketing. The result has often been seen as the chorus "high yield, low price-high price, low yield". While these concerns have not been solved, farmers continue facing the challenges of globalization and integration when foreign goods are flooded with cheap, relatively good quality $[24,25]$.

This situation raises the concern of how to make high quality products, increase added value and generate income for smallholder farmers in the rural areas. In this context, however, a serious consideration at the "endogenous development" point of view shows that Vietnam has also many comparative advantages, especially in rural areas. Specifically, each municipality has each locality, such as traditional plants, animals or the transmitted techniques from generations of traditional production. As a result, why do Vietnamese farmers have to produce strange products without relying on their own comparative advantages of traditional products? But still, there is another problem that, if we cannot control the value chains of specialties, both sellers and buyers are able to bear the loss. Thus, the successful lesson learnt from a locally-based, standardized, and value-chain development program of the Japanese rural development strategy, namely One Village One Product (OVOP) should be seriously taken into consideration. Therefore, this paper targets at reviewing the OVOP approach and considering the early adaption of this strategy in Vietnam, the case of Quang Ninh province.

\section{Literature Review}

\subsection{The Initiative OVOP Concept}

The "One Village One Product" (OVOP) approach has been recently attracted significant attention from many scholars and policy makers as a rural development strategy [26]. This OVOP concept initially started in Oita Prefecture, Japan, in 1979, by Morihiko Hiramatsu, an idea for regional development policy. The early perception of OVOP was to inspire communities in Oita of selectively producing high-quality added-value goods [27-31].

The OVOP movement suggested one village to product one competitive and marketable product with regards to their local resources to achieve sales revenue in the market, thus creating income for the residents in the villages and enhancing the local economy [32-34]. The OVOP approach also inspired local leadership and human resource development at the municipal level by founding a number of schools for specific training goals $[35,36]$. Thanks to the OVOP program, the quantity of OVOP goods in Oita enlarged from 143 goods with total values of $\$ 330$ million in 1980 to 336 products with total values of $\$ 1300$ million in 2001. Throughout that times, the Oita incomes per capita doubled, to which the attainment of the OVOP strategy appears to have contributed [37].

OVOP, under policymakers point of view, is useful at bridging the gap between urban and rural areas in developing countries through community-based development [38]. As a result, recently, the OVOP approach has been implemented in many Asian countries and further developing nations, including Africa and Latin America as alternative economic development path [39-43]. Additionally, the OVOP movement has become one of the most attractive packages of Japanese ODA (Official Development Assistance) that have great influence on the policy makers $[36,44,45]$.

\subsection{Theoretical Basis for the OVOP Concept}

The OVOP approach is targeted on motivating rural development through community-based movements by utilizing local resources and knowledge. Therefore, this strategy could be observed as being "endogenous", instead of "exogenous"' scheme as its core attributes [40]. This approach is also 
in accordance with the argument of "The key to the sustainable development of rural regions lies in the development of an independent perspective and the discovery of indigenous potential" [46-51].

Endogenous development denotes a progress of local social mobilization and involves a structural organization that carries on diverse municipal concerns to follow approved goals, a locally approved planned procedure and an approved allocation of resources with the certain target of building local capacity with regarding to skills and competencies. Endogenous development might, consequently, be regarded as a mode of progress where there is local control over the development process, where the development options are regionally decided and the welfares of growth are retained within a region [52-56].

While exogenous approach emphases on the function of central government and foreign companies, investment, thoughts and new knowledge to transform the resident economy, endogenous movement takes into account the responsibility and ability of local businesses and residents together with their control at the regional level [56-58]. Correspondingly, endogenous development is founded on the employment of regional resources, the regional capacity to examine the accumulation procedure, the aptitude to transformation, and the increase of productive mutuality at a community level $[54,59,60]$.

Lately, this model of local development has developed further to contain additional cultural, environmental, societal, and human components [1,61-64]. Friedman recognized seven essential clusters of regional resources for endogenous development: basic human needs, organized civil society, the heritage of an established environment and popular culture, intellectual and creative assets, regional resource endowment, the quality of its environment, and infrastructure [65-70]. Recently, numerous models of endogenous rural development have been widely applied in various countries through the world, namely the European Union's LEADER Initiative in 1990 or the LEADER in the UK in 1991 denotes an effort to create rural development at the "grass-roots" level [53,60]. The Leader program begins as an EU initiative but then it has been a local development approach which has been applied for 20 years as a mechanism of rural strategy that most plainly takes into consideration territorial elements [71]. Recently, it has been considered to be an fundamental rural development schemes to be implemented all around Europe, England, covering $54 \%$ of the rural population in EU [72].

In this context, the crucial component of this approach is the Local Rural Development Action Groups which were foreseen as a tool for decentralized development. The basis factors behind this pattern are territorial foundation, the use of regional assets and local contextualization over dynamic community involvement. This is the distinct ground differentiate LEADER with other strategies paying straightly on targets and plans taken at local level in the path of endogenous rural development. Another successful application of endogenous rural development approach has also been witnessed in Gippsland in the State of Victoria, Australia in which the two strategic elements of transformation: a strong economy grounded from its natural assets and the adaptive ability of local people and societies [73]. This approach has also been the case in the development of mining heritage tourism in Southern Spain or the mountain olive groves in Los Pedroches in Spain where endogenous factors has a significant influence on the development in some region not in others [74,75]. As it is also the case for Romania where the local natural and cultural capitals are considered to the key element to generate rural development during which financial, social, human resources are inefficiently established [76]. Therefore, these fundamentals namely role, capacity, and control of regional performers, and employment of local properties are bases to consider OVOP as endogenous development.

\subsection{Three Principles for the OVOP Approach}

There are three principles in the OVOP movement: Local yet global, Self-Reliance and Creativity and Human Resource Development [26,37,39,77-79] (See Figure 1). 


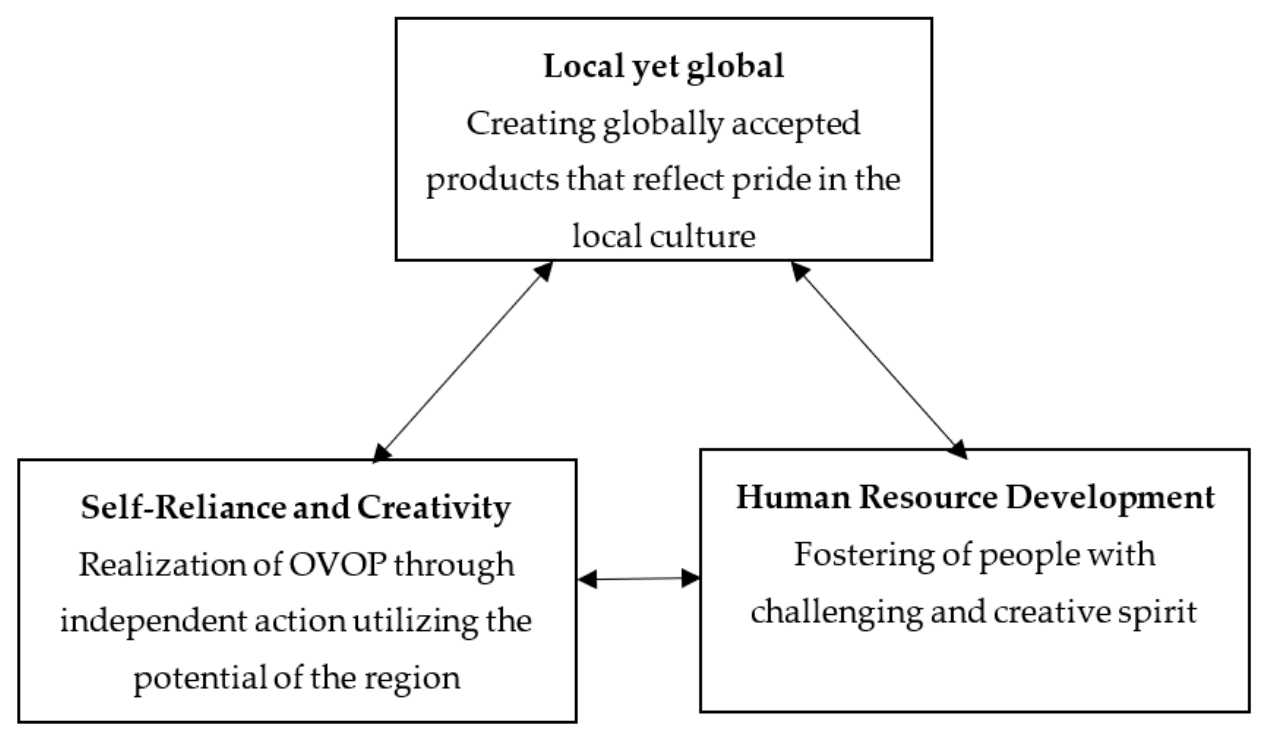

Figure 1. Three basic principles of OVOP. Source: [26].

- Local yet global

This principle introduces the mechanism to develop new products, meaning that creating globally accepted products that reflect pride in the local culture or "Think Globally, Act Locally" $[28,37,80]$. This principle denotes that exploitation of local assets is a fundamental aspect of products. While conserving the taste of local culture, develop products that are attractive both locally and globally [36]. Consequently, a product with distinctive 'local flavors and culture' can be aggressive in trading providing that its value is increasingly developed. Therefore local resources in OVOP take in several forms and component providing that they involve the worth of "local" [32,37].

- Self-Reliance and Creativity

This principle stresses self-reliance of local people and the perspective of authority for it. The authorities just offer supplementary support namely technical aid and promoting without offering direct supports to the locality. By this point, the OVOP concept is in line with the neoliberal opinion of "small government" [81] taking that self-reliance is a situation in which choices and movements happen at all stages are grounded on self-confidence and self-determination; then the movement could be applied by the localities themselves possibly thanks to the support from authorities.

- Human Resource Development

The third principle of the OVOP concept emphasizes on human resource development. Human resource development is a fundamental element of the initial OVOP idea. Local residents are expected to have a capability for alleviating poverty issues by themselves, meaning that local people do not lay on the government in producing and developing their products. These local headers are supposed to draw out the vitality of the localities and to promote their self-reliance. OVOP highlights a relation between human development and product development. The lesson learnt from this principle is that human resource development is attained in the progress to create OVOP product, alternatively, OVOP goods can be created by dedicated and skilled human resources who are inspired to contribute to their areas.

\subsection{The OVOP Movement in Asian Context}

China was commonly considered to be the first country outside Japan to recognize the future of the OVOP concept. During 1980s, fronting serious issues of migration from rural to urban regions and drop of nearby rural communities, Shanghai city started a program, the so-called "One Hamlet, 
One Product" - to inspire the enhancement of businesses to produce products made in its nearby countryside regions, consequently motivating the economy in those regions [82,83]. At the same time, Wuhan city also implemented a program "One Village, One Treasure" [84]. This movement was continually expanded in many Asia countries [85-88]. The Philippines activated a 'One Barangay, One Product' plan. Malaysia applied the 'Satu Kampung Satu Produk' program. In the 1990s, Indonesia initiated a 'Back to Village' movement to inspire residents to come back to countryside regions $[79,89]$. Altogether of those campaigns related to local development strategies after the concept of 'OVOP' in Japan $[77,90]$.

Of the most flagships OCOP concept application is the "One Tambon One Product" program in Thailand which introduced in 2001. This strategy has been applied on a nationwide level, for more than 50,000 communities through Thailand getting distinct finances and supports to employ program involving to the strategy [78,91-95]. Cambodia and Laos have now also started that similar strategy on their country $[90,96]$. (See Table 1).

Table 1. The OVOP movement in Asia.

\begin{tabular}{cl}
\hline Nations & OVOP Movement \\
\hline China & One Hamlet, One Product Movement (Shanghai) \\
& One Town, One Product Movement (Shanghai) \\
& One Region, One Vista Movement (Shanghai) \\
& One Village, One Treasure Movement (Wuhan) \\
& One Community, One Product Movement (Jiangsu Province) \\
& One Product Movement (Jiangsu Province) \\
& One Village, One Product Movement (Shaanxi Province) \\
& One Village, One Product Movement (Jianxi Province) \\
Philippines & One Barangay, One Product Movement \\
& One Region, One Vision Movement \\
Malaysia & Satu Kampung, Satu Produk Movement \\
Indonesia & Back to Village (East Java) \\
Thailand & One Tambon, One Product Movement \\
Cambodia & One Village, One Product Movement \\
Laos & Neuang Muang, Neuang Phalittaphan Movement \\
Mongolia & Neg Baag, Neg Shildeg Buteegdekhuun \\
\hline & $\quad$ Source: [28,97].
\end{tabular}

\section{Materials and Methods}

\subsection{Methodology}

This research applies mixed methods including comprehensive literature review together with secondary data collection, Key Informant Interviews (KIIs) and Focus Group Discussions (FGDs). Firstly, key words such as "endogenous rural development", "One Village One Product", "One Tampon One Product" or "One Commune One Product" in Vietnamese "Mỗi xã phường một sản phẩm" have been searched in Scholar, Scopus, and Web of Science. At the beginning, 196 articles were chosen based on the analysis of titles, abstracts and keywords. These articles were studied in details and finally there were 99 literatures in types of academic journals, books, reports were selected as the basic ground for further analyzed. Articles were excluded beyond the scope of the research focusing only on One Village One Product under the endogenous rural development schemes and its early adaption in Vietnam.

Furthermore, a case study of OVOP adaption has been chosen to illustrate for the early adaption of this approach namely One Commune One Product (OCOP) in Quang Ninh province, Vietnam. It is the case in Quang Ninh province as it is the first province in Vietnam to piloting this strategy. Secondary data regarding the social-economics, geographic of Quang Ninh province and the process, outputs, implications after three years of operation in periods of 2013-2016 was collected from Quang Ninh 
Statistical Yearbook of 2013-2016 and Report "Evaluation of the implementation of the project "Quang Ninh province-One Commune One Product", period 2013-2016 and mission direction 2017-2020" from The People's Committee of Quang Ninh Province. Additionally, primary data was also collected by FGDs and KIIs. Specifically, 2 FGDs with 10 farmers participating in the OCOP was also organized in 2017 to capture information about opinions, perspectives, and adjustments relating to the OCOP program. KIIs with representatives in Quang Ninh province from Department of Agriculture and Rural Development, Department of Agriculture Extension, Department of Planning and Investment, Farmer Union, Cooperatives have also been arranged.

\subsection{Context of the Early Adaption of OVOP in Quang Ninh Province}

Quang Ninh is the province in the North of Vietnam. In terms of administrative boundaries, North: Lang Son province, West: Bac Ninh and Hai Duong, South: Hai Phong city and the East: Gulf of Tonkin. Total area: 6,099 km2.

The province is covered by $80 \%$ mountains that mostly situates in the North whereas a fifth of the province in the Southeast is belong to the Red river delta. Quang Ninh is also home to many islands. There are 3 cities in Quang Ninh, namely Ha Long city, Mong Cai city and Uong Bi city; Cam Pha town and 10 districts: Ba Che, Binh Lieu, Co To, Dam Ha, Dong Trieu, Hai Ha, Hoanh Bo, Tien Yen, Van Don and Yen Hung. The total population of Quang Ninh province is 1,159,500 people.

Since 2000, scientists and policy makers in Vietnam have been making efforts on applying the OVOP concept, especially in agriculture context, namely Thua Thien Hue, Binh Dinh, Ho Chi Minh City, Vinh Long. In 22/10/2013, Quang Ninh, the first province in Vietnam decided to approve the program of "Quang Ninh province-One Commune One Product (OCOP)" period of 2013-2016. The program has been developed in a systematic manner, on the basis of thorough review and correction of the limitations stated above, in accordance with the following principles: be aware of and comply with the three principles of OVOP Japan; a thorough understanding of community and community products (including available and potential products) and participation of all related sectors, especially the government. (See Figure 2).

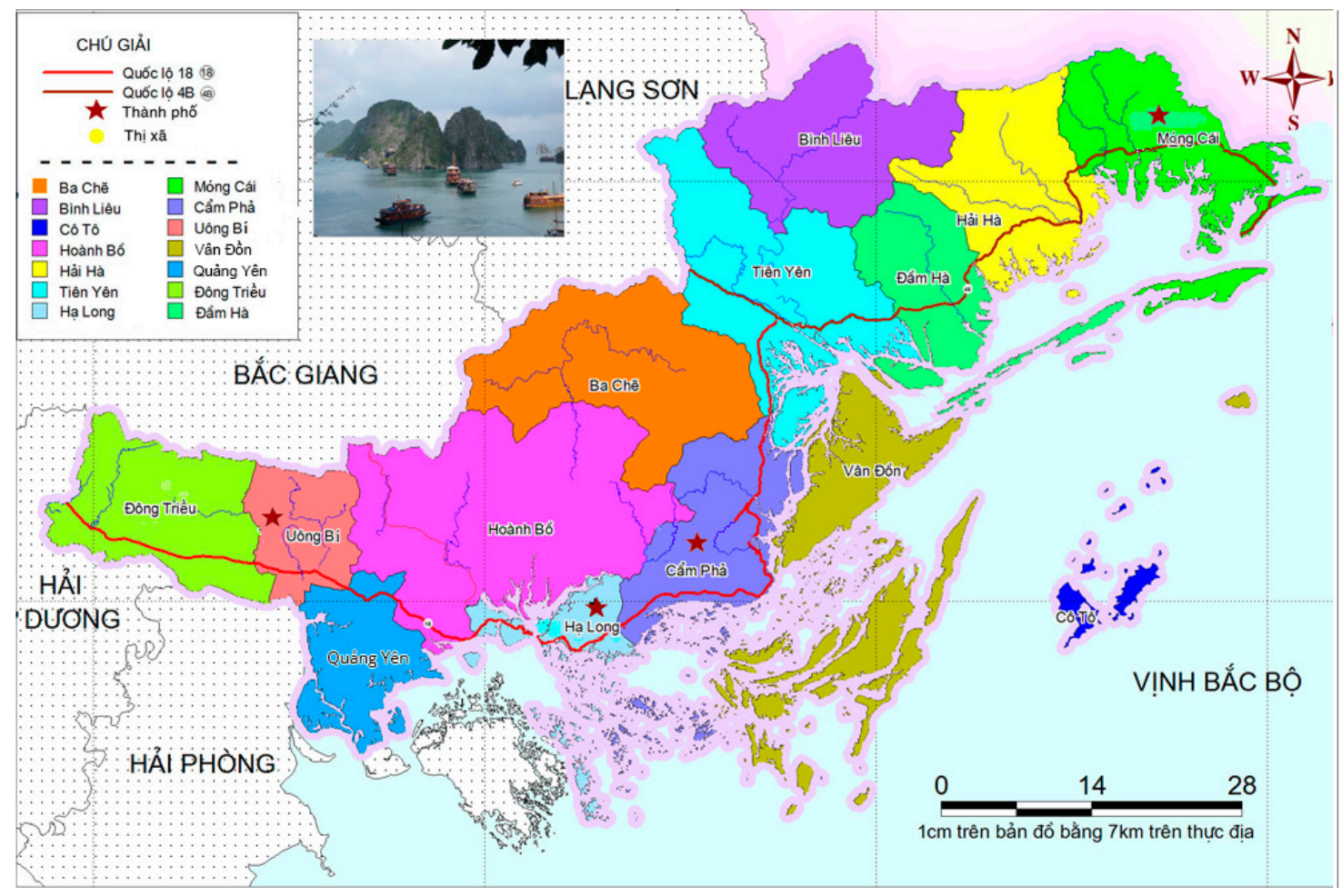

Figure 2. Map of Quang Ninh province. 


\subsection{The One Commune One Product (OCOP) Strategy in Quang Ninh Province}

- Objectives

The OCOP program purposes of developing the forms of organization and production of traditional and comparative products in communes, wards and townships, which contribute to the restructure Quang Ninh economy towards the endogenous development concept and increasing added value to effectively implement the group of criteria "Economic and organizational forms of production" in the National criteria for new rural construction. The development of production in rural areas would limit the reduction of rural migration to the city, protecting the environment and preserving the rural society.

Specifically, the OCOP program objects to building business activities for 40-60 traditional products; upgrading and developing the value chain of 20-30 traditional products with potentiality for commercialization; establishing 10-15 community-based organizations and restructuring 10-15 existing organizations to develop and commercialize traditional products; forming the promotion and product promotion system.

- Principles

$\checkmark \quad$ Local Action-Towards Global

This principle encourages people to recognize and take advantages of available locally resources. Thus, municipalities could develop products that have the ability to access to global markets by increasing added value for these products to meet standards for the international demand.

$\checkmark$ Self-Reliance, Self-Confidence and Creativity

In order to compete in the global market, local residents need to continually develop their own unique values by the spirit of self-reliance, self-confidence and creativity.

$\checkmark$ Human resources development

Thanks to the OCOP program, community leaders, heads of economic organizations (enterprise directors, co-operatives, and co-operative groups), qualified human resources as well as networks are created and developed in a sustainable way.

\section{Results}

\subsection{Establishment of the Program Management Organization}

After three years (2013-2016) of operation, the Program Management Organization (OCOP) Quang Ninh (Steering Committees at all levels) has been developed from provincial to district levels.

At the OCOP Provincial Steering Committee level, the head is the Standing Vice Chairman of the Provincial People's Committee followed by 19 members which are leaders of the provincial departments. The Provincial Steering Committee established 4 sub-committees including: product development; Promotion; Training-Communication; Administrative-General to implement the tasks according to the objectives of the scheme.

The OCOP Steering Committee at the district level, led by the chairman or vice chairman of the district People's Committee as the head, members are the local departments and committees. The standing office of the Executive Board is the Department of Agriculture and Rural Development (or Economic Division), with one to two part-time managers. (See Figure 3). 


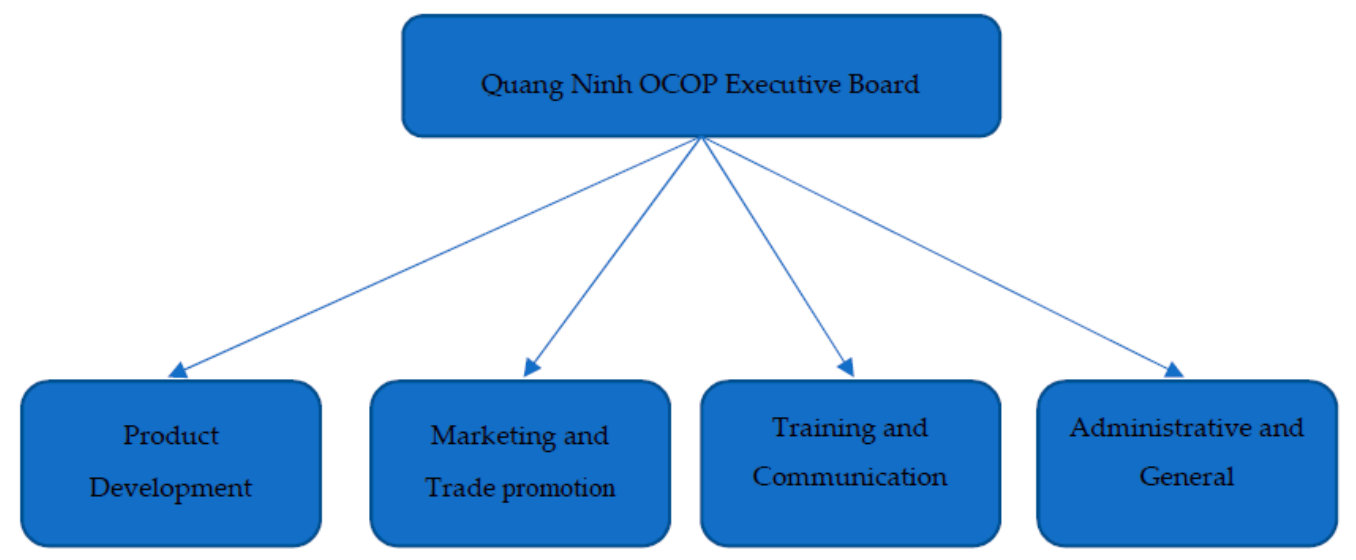

Figure 3. OCOP Steering Committee. Source: [98].

\subsection{The OCOP Cycle in Quang Ninh Province}

The key point of this program is the implementation, the so-called OCOP Cycle (Figure 4). This cycle has been built on the basis with some additional points of OTOP Thailand by 6 steps.

- $\quad$ Step 1: Publicity, guide about OCOP program

As one of the vital core elements of the OCOP program is local people so they are expected to know, discuss, implement, test and benefit from the OCOP.

- $\quad$ Step 2: Receive ideas about products

After being informed about the OCOP, people started the cycle by developing and submitting product ideas to the OCOP. Each product idea will be reviewed and selected the best ideas. Owners of these ideas will receive the "Training 1" based on their product idea.

- $\quad$ Step 3: Receive business plan

After "Training 1", the selected product owners will continue to develop business plans and submit them to the OCOP. If selected, the owners of these business plans will receive "Training 2" on how to implement the business plan.

- $\quad$ Step 4: Implement the business plan

After the Training 2, the owner of the business plan will carry out the activities according to his plan with the support of the OCOP system. During these periods, local people receive on-site supports, by many activities, namely: R\&D training, consultancy, contract with scientists from universities, research institutes, loans, trial product project.

- Step 5: Evaluate products at district/provincial level

After implementing under the Business Plan, the products will be evaluated, in the form of a product contest, in two stages: district and provincial level. Products with 3 or more stars of OCOP standard at the district level will continue to be evaluated at the provincial level.

- Step 6: Promotion

The selected products will be supported with trade promotion to increase the consumption; thereby achieving the ultimate goal of the OCOP program is to promote the development of community economy. 

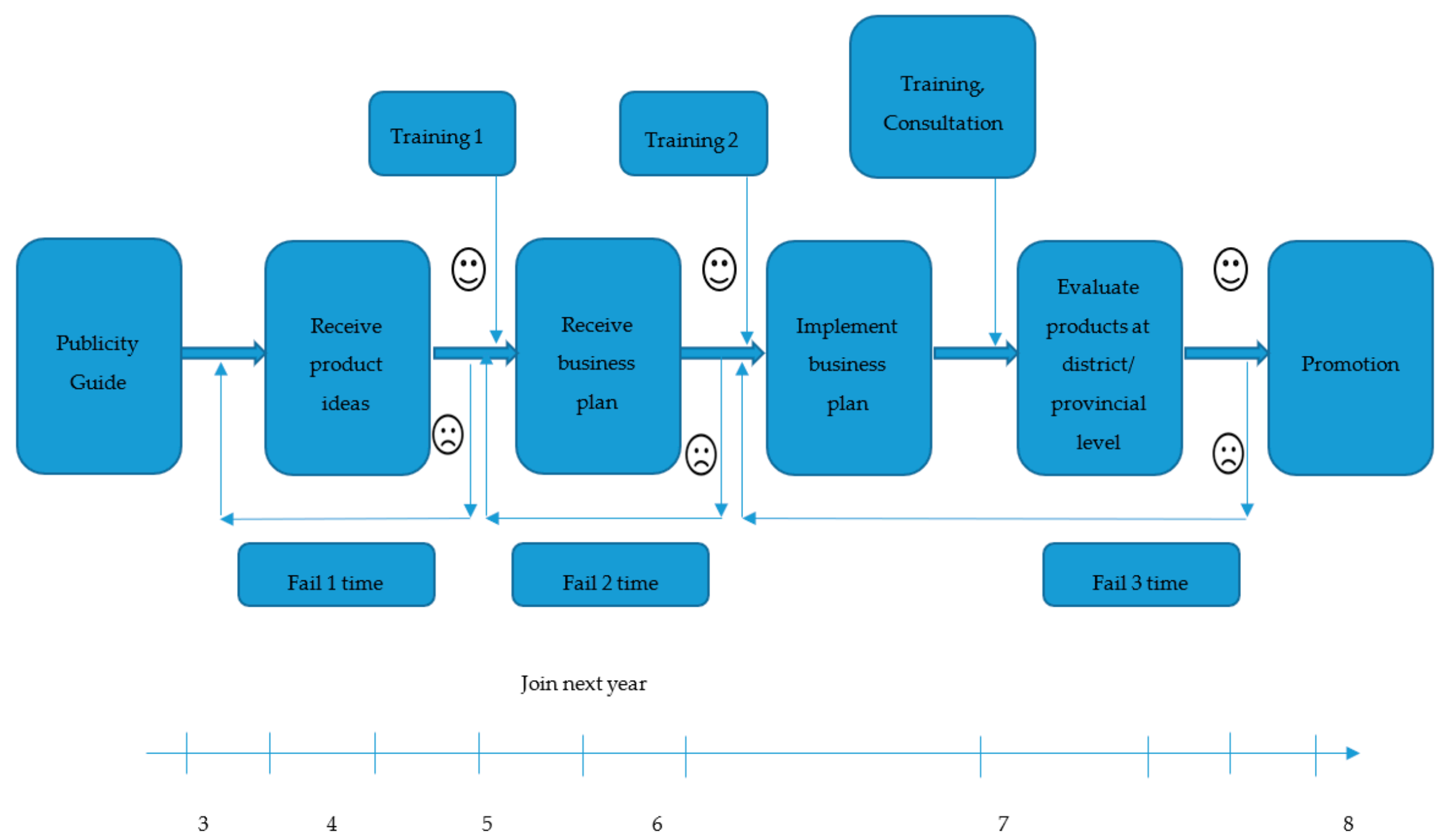

Figure 4. The annual OCOP implementation in Quang Ninh. Source: [99]. 


\subsection{Social-Economic Achievements}

After three years of implementation, the OCOP program has positively contributed to rural economic development in Quang Ninh, in particular in terms of creation of quality products, labels, brands, traceability, and better product marketing. The OCOP sales reached over 672 billion VND. Job creation has increased by over 2000 workers. (See Table 2).

Table 2. General indicators of OCOP Quang Ninh

\begin{tabular}{ll}
\hline Indicators & Value \\
\hline Total capital of participants & 5005 thousand USD \\
Total number of employees & 2172 \\
The average age of business owners, cooperatives & 44 \\
Land area, water surface of enterprises, cooperatives & 2289.86 ha \\
Total actual capital for production & 15,720 thousand USD \\
- Loans from Banks & 2935 thousand USD \\
- Support from Government & 2490 thousand USD \\
Average income per farmer (monthly) & 213-385 USD \\
\hline
\end{tabular}

Source: [98].

- Economic organization

The OCOP program has introduced 180 new economic organizations (94 households, 36 cooperatives, 32 enterprises, 11 group production, and 7 associate productions). These economic organizations will rapidly develop in size and quantity in the direction of raising the value of their products and development of production according to the value chain, which contribute to the formation of the system of production and consumption in agricultural and rural areas.

Figure 5 indicates different type of OCOP producers in Quang Ninh period of 2013-2016. A total of 180 producers were registered under OCOP program, of which household, enterprises, cooperatives, group production and association production accounted for $52 \%, 20 \%, 18 \%, 6 \%$, and $4 \%$, respectively. Additionally, newly established economic organization was: 12 enterprises, 29 co-operatives, 11 cooperative groups and 94 new production and trading households of OCOP products.

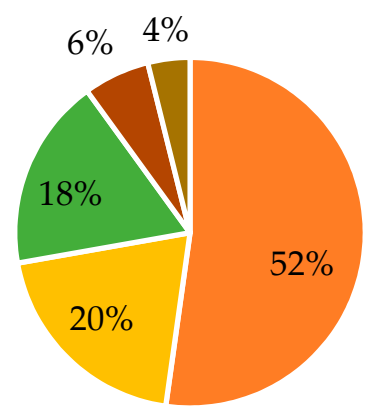

$$
\begin{array}{ll}
\square \text { Households } & \square \text { Cooperatives } \\
\square \text { Enterprises } & \text { Group production }
\end{array}
$$

- Associate Production

Figure 5. Type of producers under OCOP program in Quang Ninh (2013-2016). Source: [98].

Most of these economic models are initially effective, creating a close link between production and consumption of agricultural products, typically, the operation model of Hoa Phong Agricultural Service Cooperative (Dong Trieu Township). Farmers rent land to the cooperative, and directly participate in the production of vegetables, roots and fruits on that land. The cooperative is responsible for supplying materials and the whole process of processing and marketing the products. The specialization of 
each stage of production has contributed to the formation of habits and demands for the application of science and technology to production thus gradually increase income for farmers. Additionally, intellectual property trademark identification mark has been developed for the OCOP Quang Ninh trademark (granted by the National Office of Industrial Property-Ministry of Science and Technology in October 2015).

- OCOP's Product development

Under the OCOP Program in Quang Ninh, products have been developed from low to high and gradually improved, ensuring high standards of food safety, design, consumer acceptance (see Figure 6).

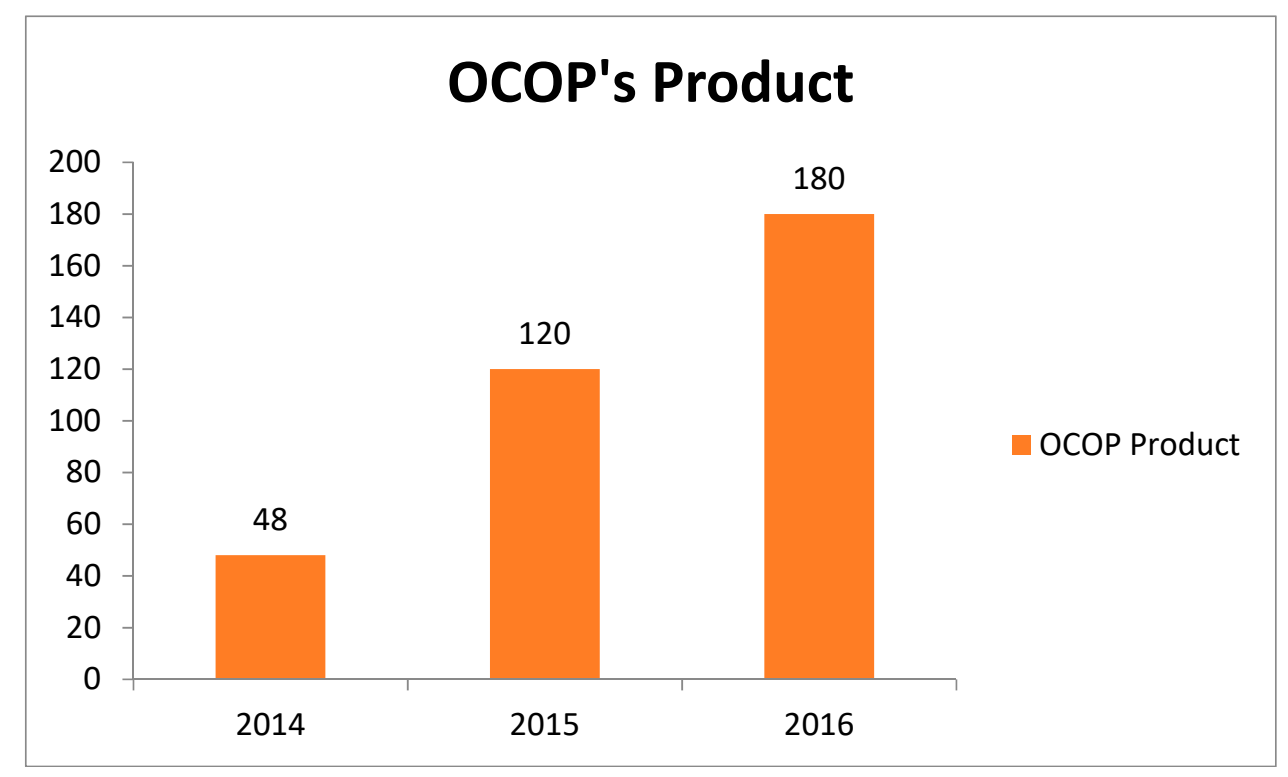

Figure 6. OCOP's Product 2013-2016. Source: [98].

In 2014, there were only 48 products (including raw, and partially finished register in the OCOP program then in 2015 this number significantly increased by 120 products, relatively complete packaging, labels, and production process. By the end of 2015, there are 21 products published quality standards appropriate. Most products have codes, bar codes as prescribed. In 2016 (9/2016), there were 198 products, the products are beautiful packaging, professional design, products of the food-food, beverages and herbal groups reach the target standards prescribed by the State.

Apart from commodity products, services and products have been developed such as Yen Dien village, Dong Trieu flower festival, Binh Lieu flower festival, Ba Chay gold flower festival, attractiveness and tourism attraction for the local.

OCOP sales from economic organizations and producers in 03 years reached 672,296 million VND (the proposed 200,000 million VND) due to increased production scale and selling price (Honey price increase from 180,000 VND/liter to 300,000 VND/liter, "Ba kích khô" from 550,000 VND/kg to $800,000 \mathrm{VND} / \mathrm{kg}$, duck eggs from VND2400/egg to VND4,000/egg). The selling prices of OCOP products significantly increased in this period because in the past, these products did not have a trademark so they were mainly consumed within the province. Currently, thanks to the OCOP program, these products have been well-recognized by trademarks, labels, packages, thus they have been not only sold in provincial market but also in the national level.

\section{Discussion}

From three years of practical implementation in Quang Ninh province, the OCOP movement is not only a purely productive development strategy but also a significant one in addressing important 
rural issues such as reducing poverty, promoting creativity and capacity of local people, building sustainable community-based organizations, increasing production and consumption, creating more jobs and the income for local people [98]. These positive results has also been in line with many other OVOP or OTOP program in many Asian countries, further developing nations, including Africa and Latin America $[28,40,42,92,100]$. The awareness of the program in authorities and local people has been remarkably improved, partly to arouse and promote the potential and advantages of localities, contribute to economic development of province $[37,39,78,100]$. Transforming from small production, self-sufficiency, up to now OCOP Program in Quang Ninh has more than 200 products, groups of products with packaging that received positive recognition from the markets in and outside the province.

In addition, self-reliance, creativity and capability of local people have been significantly improved. Participating in the OCOP, farmers have been regularly trained by the Farmer Union, Cooperatives, and Department of Agriculture Extension regarding the science and technology on increasing the productivity, quality and safe production process. As a result, productivity, quantity and value of goods in OCOP significantly increase. Local farmers have been more self-reliance reliance and able to create their own business locally, a substitute to the costly and uncertain movement to the city for searching opportunities, thus creating more jobs in rural areas. This transition would considerably contribute to reducing the rural migrant to urban areas [28,40]. According to Mr. Tran Van Thien, president of Van Don Oyster Club said that "I am completely assured that now our products already have a stable market". Thien and the other members of this club are also more reassuring after the epidemic of oyster last years; most oysters raised by the club were healthy and well developed. Another thing that Thien is excited about is his Oyster club consists only 20 members with an area of 50ha but supply over 3,000 tons of oysters annually. In addition, products participated in the OCOP strategy gets the certificates of food quality assurance from the authority which increase the distinction and value of OCOP's product.

Additionally, human resource development has also been a successful aspect of the OCOP in Quang Ninh province. OCOP program has regularly organized 32 training courses on business planning, methods and skills for production development for nearly 1,000 trainees, including managers, CEOs of enterprises, cooperatives. The program also maintains annual consultancy at local levels for managers of enterprises, cooperatives of 18 production facilities in 13 districts in Quang Ninh province. OCOP strategy has also developed a training framework and training materials on corporate governance, production management for the CEO team. Up to date, there have been 20 domestic and foreign consultancy companies participate in OCOP movement, especially development cooperation agreements, consultancy contracts on development of production in line with the value chain approach. As a result, through these training course and supported activities, leaders of small enterprises, cooperatives have been significantly improved.

Moreover, the new establishing of 180 community-based enterprises by OCOP program in the direction of increasing local community's entrepreneurial activities has also improved social capital in form of network, norm and trust. Social capital also captured by the involvement in the community has a positive impact on economic performance at micro level [40]. Thanks to the coordination and cooperation among farmers, institution and authorities, producers participating in the OCOP movement have more opportunities to share and gain techniques, information, marketing strategies, and resources. Those activities also facilitate to a stronger sense of community and levels of trust. From FGDs, being member of such institutions and organization, small producers in the OCOP program felt protected, confident and respected by the authorities regarding production activities and market. Thus, OCOP program eventually generates social capital and trust across locality, which is an important element in endogenous rural development approach.

Nevertheless, the OCOP Program in Quang Ninh province also seems to have some limitation, which has also been considered in other OVOP, OTOP movement in other countries. The guidance and implementation of the Program in some localities, departments, and units is not specific, enthusiasm 
which results in not high efficiency $[40,41,86,92]$. The connection between OCOP centers and OCOP selling points in the province together with the production units participating in the OCOP program in promoting and supplying products to the market is not frequent $[35,40]$. Thus, the output sometimes does not meet the demand of the market. Moreover the production and business management capacities of cooperatives, enterprises, and farmers are still limited [37,90].

\section{Conclusions}

This paper has studied the early adaption of the OCOP strategy in Quang Ninh province, Vietnam, on the grounded of reviewing the previous knowledge of OVOP in Oita prefecture in Japan. The OVOP strategy has been widely applied in many countries, especially in Asian nations on the basic of endogenous rural development approach taking into account three key elements of self-reliance, local capability and human resource development. After three years of piloting in Quang Ninh, the OCOP program has shown a number of outstanding results in poverty reduction, jobs creation, income improvement, local creativity and capacity enhancement, social capital increase and thus deserves to be a sustainable socio-economic development strategy.

Nevertheless, the OCOP program still has numerous of drawbacks as mentioned previously, namely unspecific guidance, weak selling points connection, and limited management capacity. Certain managerial implications should be taken into account for an effective implementation of the OCOP movement through this paper. Firstly, regarding the OCOP Steering Committees, the direction and guidance should be synchronous, drastic, dedicated but not hasty, impatient; be persevering, persistent and continuous direction of the annual cycle. Secondly, market, promotion and supported activities by authorities and government should be improved in the path of better linking between sellers and buyers. Last but not least, leaders of cooperatives, enterprises and farmers should self-enhance their knowledge; effectively participate in training courses, thereby improving the managerial skills, levels and efficiency of production and business.

Yet, as this program has been currently approved by the Vietnamese government to be implemented in the national scale; the effectiveness, feasibility and the way to apply this program should be carefully studied before any decision making of the authorities. Future research is needed to further explore on possible mechanism to facilitate OCOP in a Vietnamese context beyond the Quang Ninh province.

Author Contributions: P.L. and H.N.D.: Conceptualization, methodology, supervision; L.H.T.: writing一original draft preparation, writing-review and editing; T.M.H.H. and L.T.N.: writing-review and editing.

Funding: This research is funded by National Economics University, Ha Noi, Vietnam

Conflicts of Interest: The authors declare no conflict of interest.

\section{References}

1. Terluin, I.J. Differences in economic development in rural regions of advanced countries: an overview and critical analysis of theories. J. Rural Stud. 2003, 19, 327-344. [CrossRef]

2. Long, H.; Zou, J.; Liu, Y. Differentiation of rural development driven by industrialization and urbanization in eastern coastal China. Habitat Int. 2009, 33, 454-462. [CrossRef]

3. Ceccato, V.; Persson, L.O. Dynamics of rural areas: an assessment of clusters of employment in Sweden. J. Rural Stud. 2002, 18, 49-63. [CrossRef]

4. Barrett, C.B.; Reardon, T.; Webb, P. Nonfarm income diversification and household livelihood strategies in rural Africa: concepts, dynamics, and policy implications. Food Policy 2001, 26, 315-331. [CrossRef]

5. Sahn, D.E.; Stifel, D.C. Urban-rural inequality in living standards in Africa. J. Afr. Econ. 2003, 12, $564-597$. [CrossRef]

6. Reardon, T.; Berdegué, J.; Escobar, G. Rural nonfarm employment and incomes in Latin America: overview and policy implications. World Dev. 2001, 29, 395-409. [CrossRef]

7. Sánchez-Zamora, P.; Gallardo-Cobos, R.; Ceña-Delgado, F. Rural areas face the economic crisis: Analyzing the determinants of successful territorial dynamics. J. Rural Stud. 2014, 35, 11-25. [CrossRef] 
8. Verburg, P.H.; Eickhout, B.; van Meijl, H. A multi-scale, multi-model approach for analyzing the future dynamics of European land use. Ann. Reg. Sci. 2008, 42, 57-77. [CrossRef]

9. Bebbington, A.; Abramovay, R.; Chiriboga, M. Social movements and the dynamics of rural territorial development in Latin America. World Dev. 2008, 36, 2874-2887. [CrossRef]

10. Ambrosio-Albala, M.; Delgado, M. Understanding rural areas dynamics from a complex perspective. An application of Prospective Structural Analysis. In Proceedings of 12th Congress of the European Association of Agrarian Economists (EAAE), Ghent, Belgium, 26-29 August 2008.

11. Zhang, X.; Zhang, K.H. How does globalisation affect regional inequality within a developing country? Evidence from China. J. Dev. Stud. 2003, 39, 47-67. [CrossRef]

12. Nguyen, L.D.; Raabe, K.; Grote, U. Rural-urban migration, household vulnerability, and welfare in Vietnam. World Dev. 2015, 71, 79-93. [CrossRef]

13. Kim Anh, L.T.; Hoang Vu, L.; Bonfoh, B.; Schelling, E. An analysis of interprovincial migration in Vietnam from 1989 to 2009. Glob. Health Act. 2012, 5, 9334. [CrossRef] [PubMed]

14. Lapar, M.L.A.; Binh, V.T.; Son, N.T.; Tiongco, M.; Jabbar, M.; Staal, S. The role of collective action in overcoming barriers to market access by smallholder producers: some empirical evidence from Northern Vietnam. In Proceedings of the Workshop on Collective Action and Market Access for Smallholders, Cali, Colombia, 2-5 October 2006; pp. 2-5.

15. Taylor, P. Social Inequality in Vietnam and the Challenges to Reform; Institute of Southeast Asian Studies: Singapore, 2004.

16. Marsh, S.P.; MacAulay, T.G. Land reform and the development of commercial agriculture in Vietnam: Policy and issues. Agribus. Rev. 2002, 10, 1-19.

17. Sikor, T.; Truong, D.M. Agricultural policy and land use changes in a Black Thai commune of Northern Vietnam, 1952-1997. Mt. Res. Dev. 2002, 22, 248-255. [CrossRef]

18. Castella, J.-C.; Quang, D.D. Doi Moi in the Mountains: Land Use Changes and Farmers' Livelihood Strategies in Bac Kan Province, Viet Nam; International Rice Research Institute: Laguna, Philippines, 2002.

19. Duong, P.B.; Izumida, Y. Rural development finance in Vietnam: A microeconometric analysis of household surveys. World Dev. 2002, 30, 319-335. [CrossRef]

20. Müller, D.; Munroe, D.K. Tradeoffs between rural development policies and forest protection: Spatially explicit modeling in the Central Highlands of Vietnam. Land Econ. 2005, 81, 412-425. [CrossRef]

21. Huyen, D.N.T.N.; Tuan, D.B.A. Vietnam's Economic Development: Opportunities and Challenges towards the Integration Tendency; National Political Publishers, National Economics University: Hanoi, Viet Nam, 2004.

22. D'haeze, D.; Deckers, J.; Raes, D.; Phong, T.; Loi, H. Environmental and socio-economic impacts of institutional reforms on the agricultural sector of Vietnam: Land suitability assessment for Robusta coffee in the Dak Gan region. Agric. Ecosyst. Environ. 2005, 105, 59-76. [CrossRef]

23. McCaig, B.; Pavcnik, N. Moving out of Agriculture: Structural Change in Vietnam; National Bureau of Economic Research: Cambridge, MA, USA, 2013.

24. Truong, Q.; van der Heijden, B.I.; Rowley, C. Globalisation, competitiveness and human resource management in a transitional economy: the case of Vietnam. Int. J. Bus. Stud. 2010, 18, 75.

25. Nguyen, T.D.; Ezaki, M. Regional economic integration and its impacts on growth, poverty and income distribution: The case of Vietnam. In Computable General Equilibrium Approaches in Urban and Regional Policy Studies; World Scientific: Singapore, 2006; pp. 381-409.

26. Igusa, K. Globalization in Asia and Local Revitalization Efforts: a view from one village one product (OVOP) movement in Oita. Retriev. Febr. 2006, 18, 2015.

27. Fujita, M. Economic Development Capitalizing on Brand Agriculture: Turning Development Strategy on Its Head; Institute of Developing Economies (IDE): Chiba, Japan, 2006.

28. Igusa, K. The Problem of the Regional Revitalization in Asia and One Village One Product-Adaptability of Oita Model to Asian Countries. J. OVOP Policy 2008, 1, 5-19.

29. Knight, J. Rural revitalization in Japan: Spirit of the village and taste of the country. Asian Surv. 1994, 34, 634-646. [CrossRef]

30. Kurokawa, K. Effectiveness and limitations of the 'One Village One Product' (OVOP) approach as a government-led development policy: Evidence from Thai ‘One Tambon One Product' (OTOP). Stud. Reg. Sci. 2009, 39, 977-989. [CrossRef] 
31. Tanwattana, P. Human Development as Social Capital for Community Development: A Chronology Study of Rural Community Development in Oita Prefecture, Japan. วารสาร ญี่ปุ่น คึกษา 2010, 26, 119-141.

32. Kurokawa, K.; Tembo, F.; te Velde, D.W. Challenges for the OVOP movement in Sub-Saharan Africa. Available online: https://memberfiles.freewebs.com/15/27/73812715/documents/Challenge+for+the+ OVOP+Movement+in+Sub-Saharan+Africa.pdf (accessed on 23 November 2018).

33. Stenning, N.; Koichi, M. Knowledge and networking strategies for community capacity development in Oyama-machi: An archetype of the OVOP movement. J. OVOP Policy 2008, 1, 5-20.

34. Savitri, D. An approach of Sustainable development: Rural Revitalization as the Pioneer of OVOP movement. J. OVOP Policy 2008, 1, 79-88.

35. Triharini, M.; Larasati, D.; Susanto, R. Pendekatan One Village One Product (OVOP) untuk Mengembangkan Potensi Kerajinan Daerah. Studi Kasus: Kerajinan Gerabah di Kecamatan Plered, Kabupaten Purwakarta. J. Vis. Art Des. 2014, 6, 29-42. [CrossRef]

36. Mukai, K.; Fujikura, R. One village one product: evaluations and lessons learnt from OVOP aid projects. Dev. Pract. 2015, 25, 389-400. [CrossRef]

37. Haraguchi, N. The One-Village-One-Product (OVOP) movement: What it is, how it has been replicated, and recommendations for a UNIDO OVOP-type project. U. N. Ind. Dev. Org. Res. Stat. Branch Work. Pap. 2008, 3, 2008.

38. Denpaiboon, C.; Amatasawatdee, C. Similarity and difference of one village one product (OVOP) for rural development strategy in Japan and Thailand. Jpn. Stud. J. Spec. Issue Reg. Coop. Sustain. Futur. Asia 2012, 29, $52-62$.

39. Chidumu, J.I. The impact of "One village One Product (OVOP) on Household Income-Implications on Food Security: The Case of Bvumbwe Operation Area, Thyolo District, Malawi. PhD Thesis, Egerton University, Nakuru, Kenya, 2007, unpublished.

40. Natsuda, K.; Igusa, K.; Wiboonpongse, A.; Thoburn, J. One Village One Product—Rural development strategy in Asia: the case of OTOP in Thailand. Can. J. Dev. Stud. 2012, 33, 369-385. [CrossRef]

41. Thu, N.T.A. One village one product (OVOP) in Japan to one tambon one product (OTOP) in Thailand: Lessons for grass root development in developing countries. J. Soc. Dev. Sci. 2013, 4, 529.

42. Li, N.; Schumann, F.R. The One Village One Product (OVOP) Model and Economic Development on Guam. J. Econ. Econ. Educ. Res. 2013, 14, 21.

43. Nyamu, G.; Wagah, G.; Obala, L. The role of productive processes on the implementation of differential advantage approach in Kenya OVOP projects. J. Geogr. Reg. Plan. 2018, 11, 95-101. [CrossRef]

44. Yamazaki, J. A Comparative Analysis of One Village One Product (OVOP) and its Replicability in International Development; Erasmus University: Rotterdam, The Netherlands, 2010.

45. Dadabaev, T. Japan's ODA assistance scheme and Central Asian engagement: Determinants, trends, expectations. J. Eurasian Stud. 2016, 7, 24-38. [CrossRef]

46. Commission, E. European Spatial Development Perspective-Towards Balanced and Sustainable Development of the Territory of the European Union; Office for the official publications of the European Communities: Luxemburg, 1999.

47. Ray, C. Transnational co-operation between rural areas: elements of a political economy of EU rural development. Sociol. Rural. 2001, 41, 279-295. [CrossRef]

48. Cloke, P.; Marsden, T.; Mooney, P. Handbook of Rural Studies; Sage: Newcastle upon Tyne, UK, 2006.

49. Bessière, J. Local development and heritage: traditional food and cuisine as tourist attractions in rural areas. Sociol. Rural. 1998, 38, 21-34. [CrossRef]

50. Gannon, A. Rural tourism as a factor in rural community economic development for economies in transition. J. Sustain. Tour. 1994, 2, 51-60. [CrossRef]

51. Hayward, C.; Simpson, L.; Wood, L. Still left out in the cold: problematising participatory research and development. Sociol. Rural. 2004, 44, 95-108. [CrossRef]

52. Kis, K. The experiences of implementing LEADER approach, with special attention to effectiveness, efficiency and sustainability. Studia Univ. Babes-Bolyai 2012, 57, 34.

53. Barke, M.; Newton, M. The EU LEADER initiative and endogenous rural development: The application of the programme in two rural areas of Andalusia, Southern Spain. J. Rural Stud. 1997, 13, 319-341. [CrossRef]

54. Van der Ploeg, J.D. Born from within: Practice and Perspectives of Endogenous Rural Development; Uitgeverij Van Gorcum: Assen, The Netherlands, 1994. 
55. Van der Ploeg, J.D.; van Dijk, G. Beyond Modernization: The Impact of Endogenous Rural Development; Uitgeverij Van Gorcum: Assen, The Netherlands, 1995; Volume 3.

56. Stimson, R.J.; Stough, R.; Nijkamp, P. Endogenous Regional Development: Perspectives, Measurement and Empirical Investigation; Edward Elgar Publishing: Cheltenham, UK, 2011.

57. Dinis, A. Marketing and innovation: Useful tools for competitiveness in rural and peripheral areas. Eur. Plan. Stud. 2006, 14, 9-22. [CrossRef]

58. Vázquez-Barquero, A. Endogenous Development: Networking, Innovation, Institutions and Cities; Routledge: Abingdon, UK, 2003.

59. Garofoli, G. Endogenous Development and Southern Europe; Avebury: Marlborough, UK, 1992.

60. Shucksmith, M. Endogenous development, social capital and social inclusion: Perspectives from LEADER in the UK. Sociol. Rural. 2000, 40, 208-218. [CrossRef]

61. Murdoch, J. Networks-A new paradigm of rural development? J. Rural Stud. 2000, 16, 407-419. [CrossRef]

62. Shucksmith, M. Disintegrated rural development? Neo-endogenous rural development, planning and place-shaping in diffused power contexts. Sociol. Rural. 2010, 50, 1-14. [CrossRef]

63. Lowe, P.; Murdoch, J.; Ward, N. Networks in rural development: beyond exogenous and endogenous models. In Beyond Modernization: The Impact of Endogenous rural Development; FAO: Rome, Italy, 1995; pp. 87-105.

64. Marsden, T.; Murdoch, J.; Lowe, P.; Munton, R.C.; Flynn, A. Constructuring the Countryside: An Approach to Rural Development; Routledge: Abingdon, UK, 2005.

65. Marsden, T. Rural futures: the consumption countryside and its regulation. Sociol. Rural. 1999, 39, 501-526. [CrossRef]

66. Tregear, A.; Arfini, F.; Belletti, G.; Marescotti, A. Regional foods and rural development: The role of product qualification. J. Rural Stud. 2007, 23, 12-22. [CrossRef]

67. Margarian, A. A constructive critique of the endogenous development approach in the European support of rural areas. Growth Chang. 2013, 44, 1-29. [CrossRef]

68. Jenkins, T. Putting postmodernity into practice: endogenous development and the role of traditional cultures in the rural development of marginal regions. Ecol. Econ. 2000, 34, 301-313. [CrossRef]

69. Neumeier, S. Why do social innovations in rural development matter and should they be considered more seriously in rural development research?-Proposal for a stronger focus on social innovations in rural development research. Sociol. Rural. 2012, 52, 48-69. [CrossRef]

70. Friedmann, J. The wealth of cities: towards an assets-based development of newly urbanizing regions. Dev. Chang. 2007, 38, 987-998. [CrossRef]

71. Dax, T.; Strahl, W.; Kirwan, J.; Maye, D. The Leader programme 2007-2013: Enabling or disabling social innovation and neo-endogenous development? Insights from Austria and Ireland. Eur. Urban Reg. Stud. 2016, 23, 56-68. [CrossRef]

72. Bosworth, G.; Annibal, I.; Carroll, T.; Price, L.; Sellick, J.; Shepherd, J. Empowering Local Action through Neo-Endogenous Development; The Case of LEADER in England. Sociol. Rural. 2016, 56, 427-449. [CrossRef]

73. Sposito, V.A.; Romeijn, H.; Faggian, R. Development of Regional Production Areas in a Changing Climate: A Case Study of Gippsland, Australia. Appl. Spat. Anal. Policy 2016, 9, 365-387. [CrossRef]

74. Ballesteros, E.R.; Ramírez, M.H. Identity and community-Reflections on the development of mining heritage tourism in Southern Spain. Tour. Manag. 2007, 28, 677-687. [CrossRef]

75. Alonso Mielgo, A.M.; Sevilla Guzmán, E.; Jimenez Romera, M.; Guzmán Casado, G. Rural development and ecological management of endogenous resources: the case of mountain olive groves in Los Pedroches comarca (Spain). J. Environ. Policy Plan. 2001, 3, 163-175. [CrossRef]

76. Mikulcak, F.; Haider, J.L.; Abson, D.J.; Newig, J.; Fischer, J. Applying a capitals approach to understand rural development traps: A case study from post-socialist Romania. Land Use Policy 2015, 43, 248-258. [CrossRef]

77. Jaiborisudhi, W. OVOP Network toward in East Asia and a Case study in Thailand: The authority between the government and the general public. Int. J. East Asian Stud. 2011, 16, 14-18.

78. Noble, V. Mobilities of the One-Product policy from Japan to Thailand: a critical policy study of OVOP and OTOP. Territ. Politics Gov. 2018, 1-19. [CrossRef]

79. Saroso, D.S. The OVOP Approach to Improve SMEs Business Performance: Indonesia's Experience. GSTF J. Bus. Rev. 2017, 2, 6974.

80. Phonsuwan, S.; Kachitvichyanukul, V. Management system models to support decision-making for micro and small business of rural enterprise in Thailand. Procedia Eng. 2011, 8, 498-503. [CrossRef] 
81. Burkey, S. People First: A Guide to Self-Reliant Participatory Rural Development; Zed Books Ltd.: London, UK, 1993.

82. Zografos, D. Legal Protection of Traditional Cultural Expressions in East and Southeast Asia: An Unexplored Territory? Aust. Intellect. Prop. J. 2007, 18, 167-178.

83. Karki, B. B, doing business and role of government for entrepreneurship development. J. Nepal. Bus. Stud. 2010, 7, 53-62. [CrossRef]

84. Sturgeon, J.C. Border practices, boundaries, and the control of resource access: A case from China, Thailand and Burma. Dev. Chang. 2004, 35, 463-484. [CrossRef]

85. Dadabaev, T. Engagement and contestation: The entangled imagery of the Silk Road. Camb. J. Eurasian Stud. 2018, 2, Q4GIV6. [CrossRef]

86. Gupta, S.; Yadav, G.; Choudhary, A.; Kaur, A. Emergent Trends in Sustainable Technologies in Thailand: Developing OTOP-Based Manufacturing Capabilities in Rural India. In Promoting Socio-Economic Development through Business Integration; IGI Global: Hershey, PA, USA, 2015; pp. 48-59.

87. Kusumastuti, R.D.; Martdianty, F.; Astuti, R.D.; Nurmala, N. A Decision-Making Model for Community-Based Food Industry to Support Poverty Alleviation in East Indonesia: Case Study of East Sumba Regency. Asia-Pac. Manag. Bus. Appl. 2017, 5, 1-15. [CrossRef]

88. Sajda, N. From "OTOP" to "OSOP": Empowering the Slum through Rural Development; Södertörns Högskola: Huddinge, Sweden, 2010.

89. Widiyanti, A.; Ohno, A. A Comparative Study: One village One Product (Ovop) as an Engine of Local Economic Development in Japan and Indonesia; Universitas Gadjah Mada: Yogyakarta, Indonesia, 2016.

90. Sopheaktra, S. A Comparative Study between Japanese (Oita) and Cambodian OVOP Organizational Charts and the Three Elements of Sustainable Development. J. OVOP Policy 2008, 1, 3.

91. Available online: thaitambon.com (accessed on 23 November 2018).

92. Claymone, Y.; Jaiborisudhi, W. A study on one village one product project (OVOP) in Japan and Thailand as an alternative of community development in Indonesia. Int. J. East Asian Stud. 2011, 16, 51-60.

93. Kemavuthanon, S. Leadership in the OVOP and similar movements: The comparative study between the OVOP movement in Japan and OTOP project in Thailand. Int. J. Public Adm. 2014, 37, 542-555. [CrossRef]

94. Saifon, S.-I. Rural Socio-Economic Development: Sustainable Agriculture Dependent on Utilizing Regional Resources Comparing Japan and Thailand; Mie University: Tsu, Japan, 2017.

95. Viriyavejakul, C. Web Advertising Design for 'One Tambon One Product' Products for Thailand's Entrepreneurial Small and Medium Enterprises. In EdMedia: World Conference on Educational Media and Technology; Association for the Advancement of Computing in Education (AACE): Waynesville, NC, USA, 2015; pp. 1882-1890.

96. Hirohata, N. One village one product movement in Laos. Available online: http://web.cc.yamaguchi-u.ac. jp/ \{\}eimanage/vol3issue2/OVOP-Hirohata-31-35.pdf (accessed on 23 November 2018).

97. Warr, P.G. Is growth good for the poor? Thailand's boom and bust. Int. J. Soc. Econ. 2000, $27,862-877$. [CrossRef]

98. OCOP. Report of OCOP Period 2013-2016; OCOP: Dallas, TX, USA, 2017.

99. Ninh, O.Q. Instruction for Operation of OCOP Program; Quang Ninh Province, 5/2014; OCOP Quang Ninh: Quang Ninh, Vietnam, 2014.

100. Schumann, R.F. A Study of One Village One Product (OVOP) and Workforce Development: Lessons for Engaging Rural Communities around the World. Available online: https://www.jil.go.jp/profile/ documents/f.chumann.pdf (accessed on 23 November 2018).

(C) 2018 by the authors. Licensee MDPI, Basel, Switzerland. This article is an open access article distributed under the terms and conditions of the Creative Commons Attribution (CC BY) license (http://creativecommons.org/licenses/by/4.0/). 